\title{
ODVODENIE 3-D MODELU POVRCHU KORÚN LESNÉHO PORASTU A DETEKCIA KORÚN STROMOV Z LETECKÝCH SNÍMOK S VYSOKÝM ROZLÍŠENÍM
}

\author{
Tomáš Bucha ${ }^{1}$, Miroslav Juriš ${ }^{2}$, JozeF Vladovič ${ }^{1}$

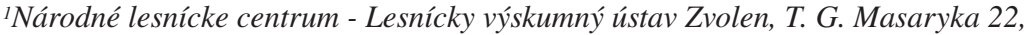 \\ SK-96092 Zvolen, e-mail: bucha@nlcsk.org \\ ${ }^{2}$ Národné lesnícke centrum - Ústav lesných zdrojov a informatiky Zvolen, Sokolská 2, \\ SK - 96052 Zvolen
}

Bucha T., Juriš M., Vladovič J., 2011: Derivation of a 3-D forest canopy model and detection of tree crowns from high-resolution aerial photos. Lesn. Čas. - Forestry Journal, 57(4): 225-236, 6 fig., tab. 5, ref. 20. Original paper. ISSN $0323-1046$.

This paper presents our proposal of a methodology procedure aimed at derivation 3-D forest canopy model from aerial multi-spectral stereo photos with a high resolution. Digital model is derived from photos using methods of digital photogrammetry. Furthermore, we used this model to determine the tree tops. For this purpose we created a system of criteria based on mathematical and logical relations. Tree tops represent the number of trees in the forest stand. We examined the accuracy of this classification on 5 areas. Errors of automated classification compared to terrestrial measurements ranged from underestimation by $41 \%$ to overestimation by $40 \%$. It would require to incorporate a spectral information into the process of tree tops determination in order to improve the classification.

Key words: 3-D forest canopy model, digital photogrammetry, tree-top, aerial photos

\begin{abstract}
V práci prezentujeme návrh metodického postupu odvodenia 3-D modelu povrchu korún lesného porastu z leteckých meračských multispektrálnych stereosnímok s vysokým rozlíšením. Digitálny model odvodzujeme zo snímok metódami digitálnej fotogrametrie. Následne sme model využili pri určení vrcholov stromov a vymedzení korún. K tomu sme vytvorili systém kritérií založený na matematickologických vztahoch. Vrcholy stromov reprezentujú počet stromov v poraste. Správnost klasifikácie sme preverili na 5 plochách. Chyby automatizovanej klasifikácie sa pohybovali od podhodnotenia o $41 \%$ po nadhodnotenie o $40 \%$ pri porovnaní s terestrickými meraniami. Spresnenie klasifikácie si vyžiada zapracovanie spektrálnych informácií do procesu ohraničenia korún stromov.
\end{abstract}

Klúčové slova: 3-D model porastu, digitálna fotogrametria, koruna stromu, letecká snímka

\section{1. Úvod a problematika}

Zavedením digitálnej fotogrametrie ako rutinnej metódy na vyhodnotenie leteckých meračských snímok do lesníckej praxe sa vytvorili predpoklady pre racionalizáciu mapovacích prác v lesníctve (ŽIHLAVNík et al. 2005, HaLVoŇ 2008). Kvalitne pripravený stereoskopický model snímok je základom pre odvodenie digitálneho modelu terénu (DMT), pre vytvorenie ortofotosnímok a ortofotomáp a d’alších lesníckych aplikácií, akými sú určenie stromových a štrukturálnych porastových cha- rakteristík. Príkladmi sú napríklad odvodenie výšok ADLER (2001) a ohraničenia korún stromov PITKÄNEN (2001), Pouliot et al. (2002), Šumbera (2003), MaJlinGOVÁ (2007), MATĚJKA (2008). Uvedení autori vychádzali z predpokladu, že vrchol stromu je možné detekovat na základe najvyššej hodnoty jasu, to jest že vrchol koruny je najsvetlejší. Okraj koruny naopak predstavuje minimálna hodnota jasu. Pre spresnenie algoritmov sa zaviedli prahové hodnoty vo vztahu k spektrálnym hodnotám odrazivosti snímky alebo limitná vel'kosê 


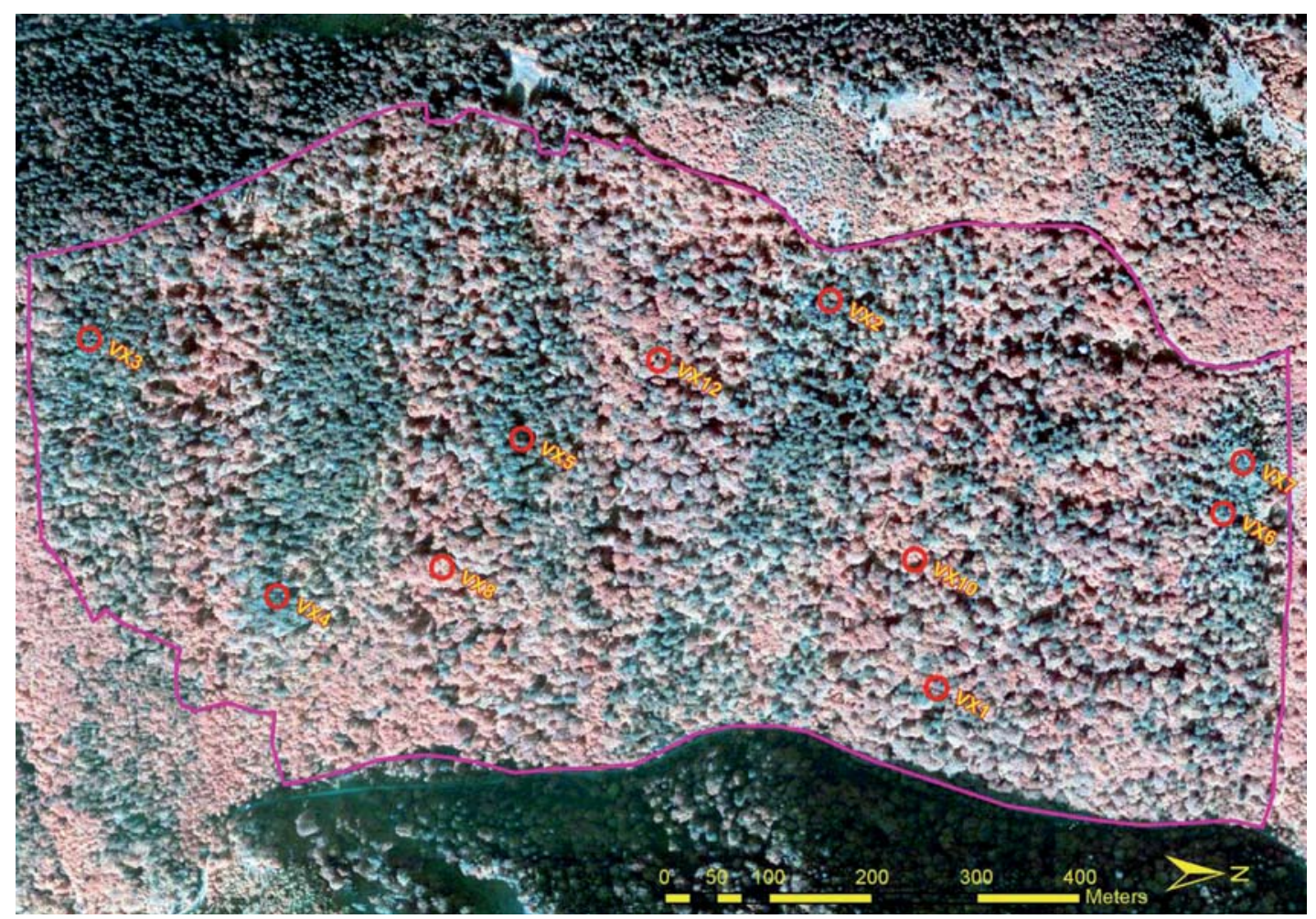

Obr. 1. Modelové územie Medvedia úboč s lokalizáciou výskumných plôch: CIR kompozícia na mozaike leteckých snímok z roku 2009. Kombinácia kanálov infračervený, červený a zelený kanál. Zrejmá je rozdielna textúra porastov, v závislosti od veku a spôsobu vzniku ako aj rozdielny spektrálny prejav ihličnatých a listnatých drevín. LS Predajná, Lomnistá dolina - lokalita Medvedia úboč

Fig. 1. Test area Medvedia úboč with localization of research plots: CIR composition on the mosaic of aerial photos from 2009. Combination of channels - infrared, red and green. Evident differences in forest stands texture, according to the age and origin as well as different spectral display of coniferous and broad-leaved tree species. LS Predajná, Lomnistá dolina - Locality of Medvedia úboč

priemeru koruny. RAWERT (2004), POONE et al. (2005), HiRSCHMUGL et al. (2007) využívajú stereosnímky na odvodenie digitálneho modelu povrchu porastu. Následne ho využívajú na vymedzenie korún jednotlivých stromov, a to v kombinácii s postupmi založenými na spektrálnych vlastnostiach snímok, na maximálnej a minimálnej odrazivosti na vrchole koruny a na okraji koruny. Ide o príklad syntézy poznatkov z oboru dvojsnímkovej leteckej fotogrametrie a klasifikácie obrazu z oboru dialkového prieskumu Zeme (DPZ). Nedoriešené ostáva polohové stotožnenie DMT a snímky. Napr. HiRSCHMUgl et al. (2007) to riešili vytvorením DMT zo snímok s pozdížnym prekrytom $90 \%$. WOLF \& HeIPKE (2007) navrhli postup na automatizované ohraničenie korún stromov z ortorektifikovaných infračervených snímok v kombinácii s DMT založený na fuzzy logike a aproximácii koruny stromov elipsou.

Z daného rozboru problematiky vyplýva, že s rozvojom technológií sa aj v lesníctve zvyšuje záujem o využitie celého potenciálu leteckých meračských snímok (LMS). Napriek tomuto úsiliu pre podmienky našich lesov nie sú vyvinuté prakticky realizovatel'né metódy (algoritmy) pre automatizované zistovanie stromových a porastových taxačných veličín lesných porastov založené na kombinácii spektrálnych a geometrických vlastností korún stromov. V našej práci sa zaoberáme využitím digitálnych leteckých meračských multispektrálnych snímok (LMMS) s vysokým rozlíšením pri odvodení 3-D modelu povrchu korún porastu, z ktorého odvodzujeme prvky vnútornej štruktúry lesných porastov, a to vrcholy stromov a koruny stromov. Použitý prístup je založený na využití metód digitálnej fotogrametrie pri tvorbe 3-D modelu povrchu korún a matematicko-logických vztahov pri určení vrcholov a vymedzení korún stromov. Cielom je navrhnút prakticky aplikovatelnú metódu na odvodenie uvedených prvkov výstavby porastov ako súčasti tematického mapovania a klasifikácie priestorovej štruktúry porastov.

\section{Metodika a materiál}

\subsection{Základná charakteristika hodnoteného územia}

Modelové územie Medvedia úboč sa nachádza v Lomnistej doline (obr. 1), v lesnej oblasti 46Ba Nízke Tatry, podoblasê Ďumbier, Prašivá, časê juh (VLadovič et al. 1994). Organizačne patrí do lesnej správy Predaj- 

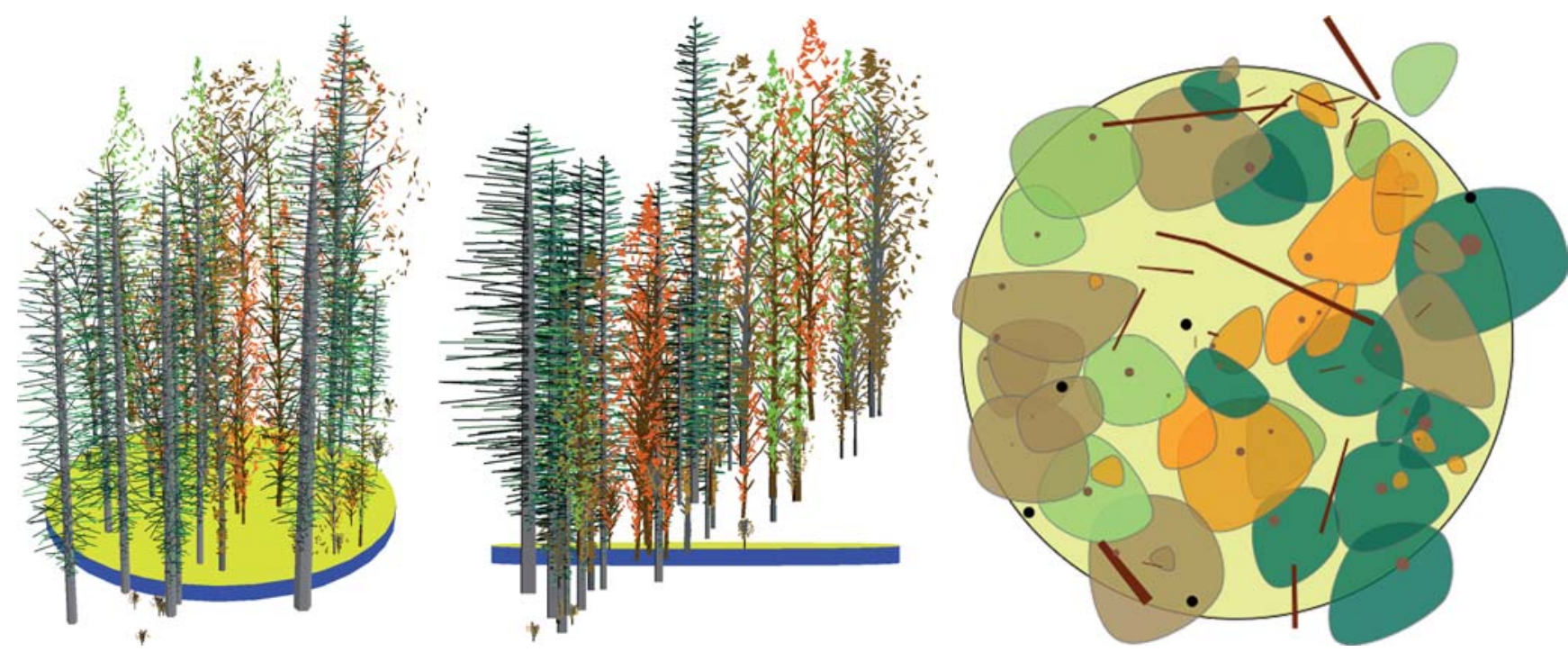

Obr. 2. Výskumná plocha VX 1 podrobne meraná technológiou FieldMap - vizualizácia jednotlivých stromov, projekcií korún, ležiaceho i stojaceho odumretého dreva, druhovej, vertikálnej a horizontálnej výstavbovej štruktúry drevinovej zložky

Fig. 2. Research plot VX 1 measured in detail with FieldMap technology-visualization of individual trees, projections of tree crowns, lying and standing dead-wood, species, vertical and horizontal structure of tree species composition

ná. Územie je charakteristické tým, že ide o zachovalý komplex prevažne prírodných lesov na stanovištiach v kategórii lesov ochranných s prevažujúcou funkciou ochrany pôdy. Výmera spracovaného územia je približne 100 ha a jeho prevažujúca čast sa stotožňuje s modelovou lokalitou, ktorá bola v r. 2009 a 2010 predmetom podrobného výskumu a tematického mapovania v rámci vedeckého projektu „Výskum metód klasifikácie a štrukturálnych modelov priaznivého stavu lesných ekosystémov Slovenska - Hodnotenie stavu a vývoja lesov v krajine s podporou DPZ“. Posudzované územie má priemerný sklon terénu $32^{\circ}$. Nadmorské výšky sa pohybujú od 684 do $1054 \mathrm{~m} \mathrm{n}$. m. Podklad je tvorený metamorfovanými horninami, prevažujú migmatizované ortoruly a niekolko ostrovov amfibolitov. Územie sa nachádza $\mathrm{v}$ jedlovo-bukovom vegetačnom stupni. Lokalita sa v rámci výskumu v uvedenom projekte podrobne typologicky zmapovala segmentovou metódou. Bola vyhotovená tiež podrobná litogeografická mapa. Prevažujúce skupiny lesných typov v zmysle geobicenologickej typizácie sú Abieto-Fagetum nst (33\%), Fageto-Abietum nst (27\%), Fageto-Aceretum nst (26\%), Fraxineto-Aceretum nst (12\%). V každom segmente sa zaznamenal aj aktuálny stav drevinovej zložky na úrovni súborov porastových typov (SPT). Prevažujúce SPT sú jedlové bučiny $(51 \%)$, porasty jedle s listnáčmi $(22 \%)$, bučiny s cennými listnáčmi (14\%), cenné listnáče a ich zmesi (7\%), smrekovo-bukové jedliny (6\%).

V rámci citovaného projektu sa v modelovej lokalite založilo 10 trvalých výskumných plôch kruhového tvaru so štandardizovanou výmerou $1000 \mathrm{~m}^{2}$. GPS metódou boli zamerané stredy plôch, technológiou FieldMap pozície jednotlivých stromov na ploche. Zamerané boli priemety korún stromov, výška nasadenia koruny, hrúb$\mathrm{ka} \mathrm{d}_{1,3}$ a výšky stromov. Výskumné plochy sa zakladali ako reprezentatívne pre plošne prevažujúce štrukturálne typy posudzovaného územia. Plochy sú vizualizované v prostredí ArcGIS a v systéme Stand Visualisation System (SVS) (obr. 2). V našej práci sme 5 plôch využili pri overení správnosti klasifikáciách počtu stromov z LMMS.

\subsection{Letecké snímkovanie a spracovanie snímok}

Letecké snímkovanie sa realizovalo v rámci obnovy LHP na lesných celkoch v obvode LS Predajná. Parametre snímkovania sú uvedené v tabul'ke 1. Organizačné a administratívne práce ako aj všetky náležitosti leteckého meračského snímkovania zabezpečila firma Photomap, s. r. o., Košice. Samotné snímkovanie realizovala firma ARGUS GEO SYSTÉM, s. r. o., Hradec Králové v dňoch 1. 9. 2008 a 22. - 23. 7. 2009 digitálnou kamerou Vexcel Ultracam X v 4 pásmach, a to modrom, zelenom, červenom a infračervenom. Dodané snímky boli rádiometricky upravené, s multispektrálnymi kanálmi prevzorkovanými na priestorové rozlíšenie panchromatického kanála.

\subsection{Podkladové materiály}

Využili sme lesnícke porastové mapy záujmového územia mierky 1 : 10000 so stavom $\mathrm{k}$ roku 2000. Údaje o porastových charakteristikách jednotlivých jednotiek priestorového rozdelenia lesa (JPRL) sme získali z lesného hospodárskeho plánu (LHP) z opisu porastov pre Lesný celok (LC) Lesy Jasenie. Obnova LHP sa uskutočnila v roku 2000. Údaje z LHP slúžili ako podporné údaje pre spracovanie a vyhodnotenie leteckých snímok. Digitálny model reliéfu (DMR) sme získali cez mapovú 
Tabul'ka 1. Parametre leteckého snímkovania

Table 1. Flight parameters

\begin{tabular}{|c|c|}
\hline Meno lokality ${ }^{1)}$ & Chabenec \\
\hline Mierka snímkovania²) & 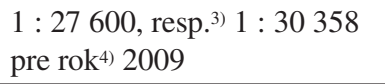 \\
\hline Prekryt pozdížny5) $p$ & $60 \%$ \\
\hline Prekryt priečny ${ }^{6)} \mathrm{q}$ & $20 \%$ \\
\hline Dátum snímkovania ${ }^{7)}$ & $\begin{array}{l}\text { 1.9. 2008; 22. 7. } 2009 \\
\text { (23. 7. 2009) }\end{array}$ \\
\hline Hodina snímkovania ${ }^{8)}$ & $\begin{array}{l}12,20-13,51 ; 10,45-11,32 \mathrm{~h} \\
(8,40-8,50 \mathrm{~h})\end{array}$ \\
\hline $\begin{array}{l}\text { Konštanta fotokomory9) } \\
(\mathrm{mm})\end{array}$ & 100,5 \\
\hline Snímkový formát ${ }^{10)}$ & $14430 \times 9420$ pixelov \\
\hline Typ fotokomory ${ }^{11)}$ & $\begin{array}{l}\text { UltraCam X - digitálna } \\
\text { multispektrána kamera }{ }^{12)}\end{array}$ \\
\hline Priestorové rozlíšenie ${ }^{13)}$ & $20 \times 20 \mathrm{~cm}$ \\
\hline Rádiometrické rozlíšenie ${ }^{14)}$ & $\begin{array}{l}\text { modrý - zelený - červený } \\
\text { - blízky infračervený kanál. } \\
\text { Úroveň spracovania } 3^{15)}\end{array}$ \\
\hline Filter ${ }^{16)}$ & bez filtra ${ }^{17)}$ \\
\hline $\begin{array}{l}\text { Plocha analyzovaného úze- } \\
\text { mia Medvedia úboč18) }\end{array}$ & 100 ha \\
\hline
\end{tabular}

${ }^{1)}$ Locality, ${ }^{2}$ Scale of aerial photography, ${ }^{3)} \mathrm{Or},{ }^{4} \mathrm{For},{ }^{5}$ Longitudinal overlap, ${ }^{6)}$ Cross overlap, ${ }^{7)}$ Date of aerial photography, ${ }^{8)} \mathrm{Hour}$ of aerial photography, ${ }^{9}$ Camera constant, ${ }^{10}$ Image format, ${ }^{11}$ Camera type, ${ }^{12}$ Digital multi-spectral camera, ${ }^{13}$ Spatial resolution, $\left.{ }^{14}\right)$ Radiometric resolution, ${ }^{15}$ Blue - green - red - near infrared channel. Level of processing $3,{ }^{16}$ Filter, ${ }^{17}$ Without filter, ${ }^{18}$ Analyzed area of Medvedia úboč

službu Geodetického a kartografického ústavu. DMR je odvodený z výškopisu základnej mapy SR v mierke 1:10 000 .

Všetky údaje boli polohovo zjednotené v systéme JTSK. Získané údaje využívame ako referenčné k údajom odvodeným z leteckých snímok.

\subsection{Metodika vyhodnotenia snímok}

Základnou úlohou je vytvorenie digitálneho modelu terénu. $\mathrm{V}$ práci rozlišujeme termín digitálny model reliéfu (DMR) a digitálny model terénu (DMT). Termín DMR ponímame v zmysle KRCHA (1990), ktorý definuje reliéf Zeme ako pevné, ale pritom dynamické rozhranie medzi litosférou, resp. pedosférou, na jednej strane a atmosférou, resp. hydroférou na strane druhej. Termín DMT zahrňuje DMR vrátane vegetácie, budov či iných technických prvkov. Termín digitálny model povrch korún lesného porastu je v našej práci synonymom termínu DMT. V oboch prípadoch DMR aj DMT ide o modelovo odvodené rozhranie $\mathrm{v}$ počítačovom prostredí.

Postup odvodenia DMT a vymedzenia korún stromov pozostáva z krokov uvedených na obrázku 3.

\section{Príprava projektu: aerotriangulácia, interná a externá orientácia snímok}

Prípravu projektu, aerotrianguláciu, internú a externú orientáciu snímok ako aj ortorektifikáciu snímok vykonalo pracovisko dial'kového prieskumu Zeme a kartografie NLC-ÚLZI Zvolen na pracovnej stanici Image Station. Správnosł aerotriangulácie (ŠMELKO et al. 2003) vyjadrená strednou polohovou súradnicovou chybou $\mathrm{m}_{\mathrm{xy}}$ bola $\sim 0,5 \mathrm{~m}$. Pri transformácii jednotlivých snímok do systému JTSK (ortorektifikácii) sa dosiahla stredná polohová chyba $\mathrm{m}_{\mathrm{xy}} \sim 1 \mathrm{~m}$. Uvedené výsledky sú na hornej hranici, resp. prekračujú kritériá piatej triedy presnosti (STN 01 3410). Pre potreby tematického mapovania prvkov porastovej výstavby však plne postačujú. Parametre jednotlivých operácií boli uložené do projektu. Samotné vyhodnotenie snímok sme vykonali na fotogrametrickej stanici v softvéri PhoTopoL v. 9.0.2, do ktorého sme cez funkcionalitu importu načítali projekt $\mathrm{z}$ Image station so všetkými potrebnými parametrami.

\section{Epipolárna transformácia pre stereo vyhodnotenie snímok}

Po vykonaní internej a externej orientácie snímok v prostredí PhoTopoL podla parametrov z importovaného projektu sme vykonali epipolárnu transformáciu snímok. Ide o transformáciu snímok, $\mathrm{v}$ ktorej sa identické body na snímkach umiestnia do jedného riadku. Tým sa odstráni vertikálna paralaxa. Rozdiel v umiestnení identických bodov v smere $\mathrm{x}$-ovej osi snímok zodpovedá horizontálnej paralaxe.

\section{Automatizované vytvorenie siete výškopisných bodov a DMT}

Pre získanie bodov pre DMT sme použili funkcionalitu PhoTopoL na automatickú tvorbu DMT zo stereo dvojice snímok. Zo snímok sme vybrali územie o výmere asi 100 ha v lokalite Medvedia úboč. Výstupom funkcionality pre automatickú tvorbu DMT je súbor bodov - diskrétne bodové pole výšok (DBP), ku ktorým je v zvolenej súradnicovej sústave pripojená výšková súradnica $Z$. Kvalitu odvodeného DMT ovplyvňuje nastavenie viacerých parametrov:

- krok mriežky, pri „dospelých“ porastoch sa osvedčila vel'kosi $2 \times 2 \mathrm{~m}$,

- okolie záujmu bodu mriežky, najlepšie výsledky sme dosiahli s hodnotou $10 \times 10$ pixelov,

- filtrácia bodov odvodeného DMT. Využili sme preddefinované hodnoty korelačného koeficientu $(0,15)$, minimálnej vzdialenosti lúčov $(6,0)$ a rozdielu výšok menej ako $40 \mathrm{~m}$. Parameter ,rozdiel výšok" sleduje nadmorskú výšku bodov a ak sa niektorý odlíši od susedov o viac ako povolenú hodnotu z výstupu je vylúčený. Týmto spôsobom sme eliminovali chybne vypočítané výšky DBP. Ich výskyt je v podmienkach tvorby DMT v lesnom poraste vysoký. 


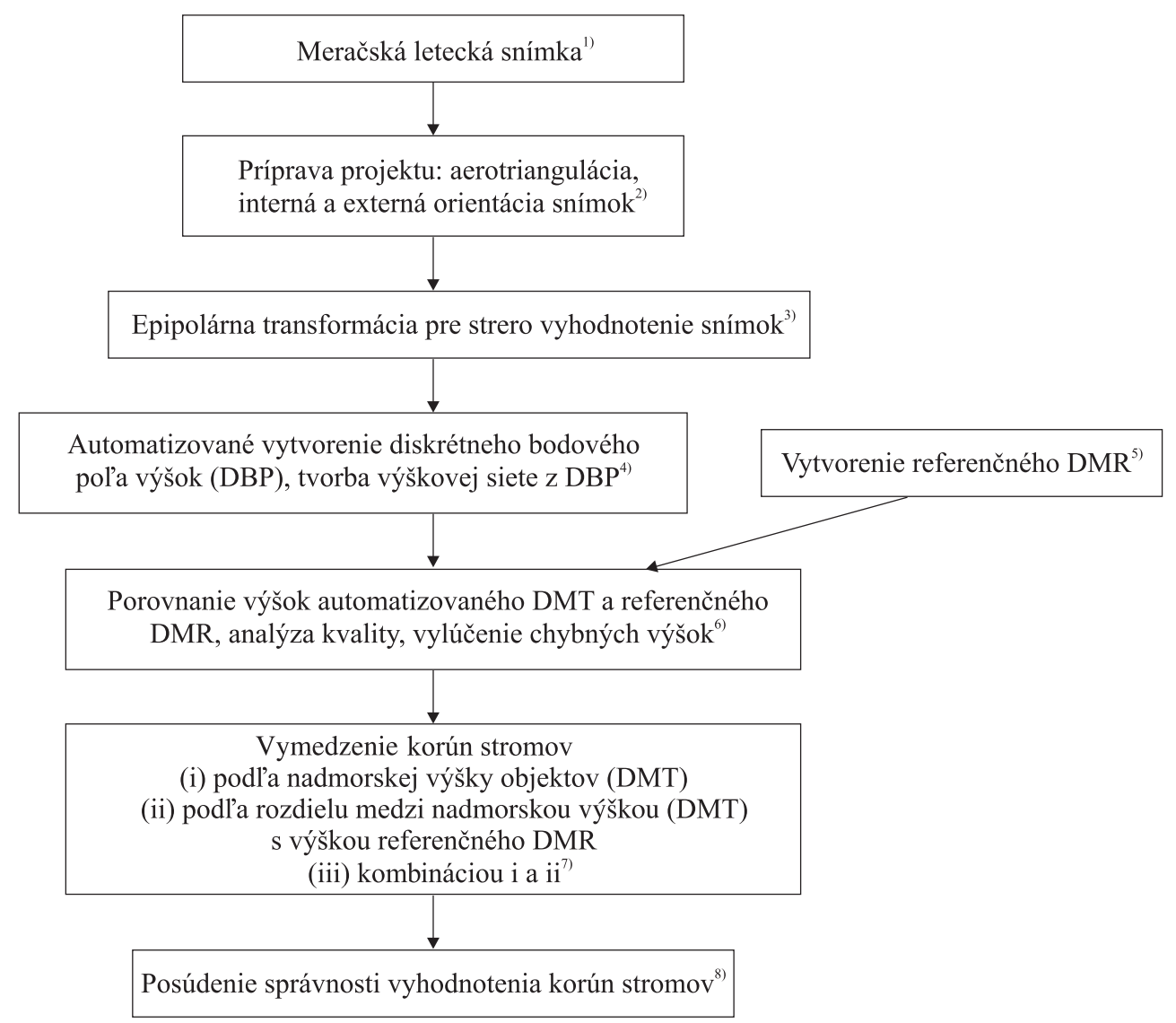

Obr. 3. Postup tvorby DMT a vymedzenia korún stromov z leteckých meračských snímok

Fig. 3. Creation of DMT and determination of tree crowns from aerial photos

Pri výpočte výšok je potrebné poznat vel'kosti horizontálnych a vertikálnych paraláx. PhoTopoL pre zjednodušenie výpočtu pracuje s epipolárnymi projekciami, pričom na vyhladávanie zodpovedajúcich si objektov na dvoch susedných stereosnímkach je využitá metóda tzv. plošne založeného párovania (Area based correlation matching). Metóda je založená na korelácii hodnôt jasu identických objektov. Výstupom z automatickej tvorby DMT je súbor bodov s výškovou súradnicou, ktorá zodpovedá nadmorskej výške povrchu korún porastu.

\section{Vytvorenie referenčného DMR a odvodenie výšky porastu}

V modelovom území sa lesné porasty nachádzajú vo výrazne sklonitom teréne (priemerný sklonom svahu je $32^{\circ}$ ). Pre vyhodnotenie výškovej diferenciácie korún stromov je preto nutné eliminovat nadmorskú výšku reliéfu. Rozdiel medzi DMT a DMR nám potom určuje výšku stromu, resp. výšku objektu v každom obrazovom prvku na snímke. Ide o jednoduchý matematický úkon, ktorého praktická realizácia je však vel'mi problematická. Dôvodom je nepoznaná nadmorská výška reliéfu. Praktické odvodenie digitálneho modelu reliéfu v lesných porastoch je prácne, ak aj metóda existuje, pod korunami stromov spravidla zlyháva, napr. laser scanové metódy. V našom riešení vytvárame referenčnú plochu z vrstevníc základnej mapy mierky $1: 10000$. Ide o zjednodušené riešenie $\mathrm{z}$ hladiska geometrickej presnosti, avšak pre potreby určenia výstavby porastu ho považujeme za postačujúce.

Jednoduchým matematickým výpočtom, rozdielom nadmorských výšok DMT a referenčného DMR získame výšku objektu (HVR): HVR = DMT - DMR.

Touto operáciou eliminujeme vplyv sklonu reliéfu na súradnicu výškopisného bodu Z. Týmto sa jednotlivé výškové body dostanú do vzájomne porovnatelnej výškovej pozície, kde porovnávacia rovina má hodnotu 0 . V d’alšom ju nazývame virtuálna rovina. Modelovo je situácia zobrazená na obrázku 4.

Z frekvenčného histogramu zastúpenia výšok HVR na celom záujmovom území vyplýva, že najpočetnejšou skupinou DBP sú body s výškou od 14 do $32 \mathrm{~m}$. $Z$ výpočtov sme ako chyby vylúčili body s extrémnymi hodnotami, v našom prípade išlo o body s hodnotami mimo intervalu $-10 \mathrm{~m}$ až $50 \mathrm{~m}$. Z hladiska d’alšieho využita údajov pri identifikácii korún stromov majú väčší význam body na hornej hranici intervalu. Tieto body majú väčší predpoklad stat sa vrcholom stromu, jadrom entity stromu. 


\section{Priradenie plochy $k$ jednotlivým výškovým bodom}

Z bodového pola výšok prostredníctvom funkcionalitu PhoTopoL „Vytvorenie oblasti z bodov“" sme vytvorili uholníkovú sief, t. j. automatizovane sa priradila oblasé ku každému výškovému bodu, ktorý sme v predchádzajúcich krokoch odvodili a ktorý prešiel stanovenými kritériami kvality. Výhodou tohto prístupu je, že medzi pôvodnými výškovými bodmi vznikajú topologické a geometrické vztahy (susedí, nesusedí, vyšší, nižší...), ktoré je možné kvantifikovat a analyzovat. Vzhladom $\mathrm{k}$ tomu, že výškové body nie sú vytvorené v pravidelnej sieti, sú vytvorené plochy nepravidelného tvaru a rôznych vel'kostí. Vel'kosê tejto plochy je daná hustotou získaného výškového bodového pola a algoritmom použitého softvéru.

\section{Výsledky}

\subsection{Vymedzenie korún stromov}

Vymedzenie korún strom sme založili na využití topologických vztahov na vytvorenej sieti DMT a formulovaní matematicko-logických kritérií odvodených z poznatkov o velkosti a tvare koruny stromu.

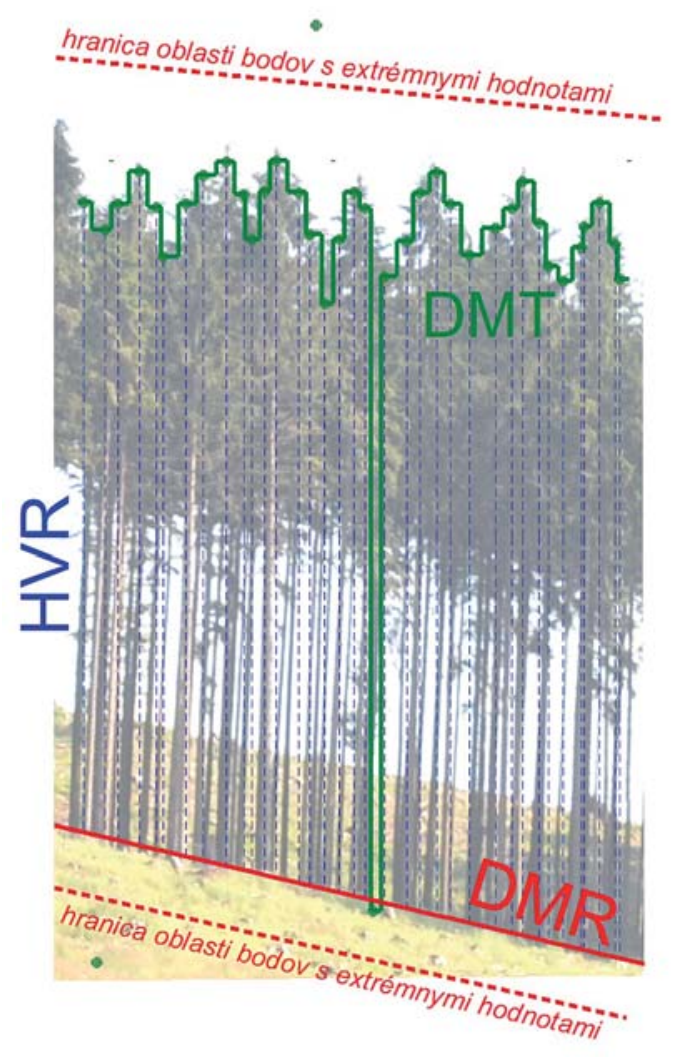

Pri určení vrcholu stromu v skupine plôch sme preverili dva varianty. V prvom variante vychádzame pri určení vrcholu v skupine plôch z DMT s absolútnymi nadmorskými výškami (obr. 5 vlavo). Vrcholom je vztažný bod plochy ('ažisko plochy), ktorej n.m.v. je vyššia ako n.m.v. susedných plôch. Ak sa vedla seba nachádzajú dve alebo viac vrcholových plôch, tieto sa agregujú a vztažný bod novej (zlúčenej) plochy sa stáva vrcholom.

V druhom variante sme pri určení vrcholu stromu metodicky postupovali totožne, avšak namiesto nadmorskej výšky DMT sme použili rozdiel výšok $H V R$ vypočítaný podla vzlahu: $H V R=D M T-D M R$. Vstupná vrstva je zobrazená na obrázku 5 vpravo.

Pre zistenie plôch, ktoré sú výškovo dominantné a je predpoklad, že budú zodpovedą vrcholcom stromov boli napísané aplikačné formuláre $\mathrm{v}$ internom jazyku PhoTopoL, v jazyku Topas.

V d’alšom kroku sme priradili k vrcholu širšiu oblast - entitu. Pod entitou rozumieme skupinu plôch prislúchajúcu $\mathrm{k}$ jednému vrcholu. $\mathrm{V}$ ideálnom prípade by každá entita mala predstavovat korunu jedného stromu $\mathrm{v}$ poraste. Pre priblíženie sa $\mathrm{k}$ tomuto ideálnemu prípadu sme vytvorili systém kritérií, na základe ktorých prirad’ujeme jednotlivé plochy $\mathrm{k}$ entite:

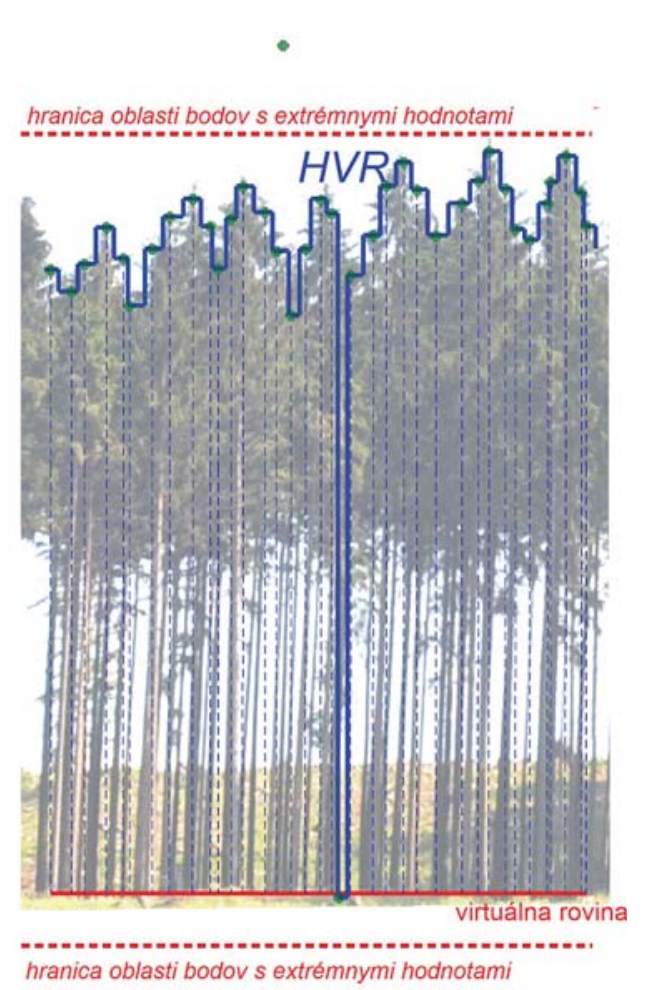

Obr. 4. Na obrázku vlavo je zobrazený reálny stav porastu. Na obrázku vpravo je zobrazene situácia po prepočítaní súradnice Z vzhladom k virtuálnej rovine (HVR = DMT - DMR)

Fig. 4. Picture shows a real condition of the forest stand on the left. On the right side it shows the situation after recalculation of $Z$ coordinates relative to the virtual plane $(H V R=D M T-D M R)$ 
- nadmorská výška plochy je nižšia ako vrchol,

- testovaná plocha vo vztahu k vrcholu leží na pomyselnej línii, tvorenej vzłažnými bodmi plôch ležiacimi medzi testovanou plochou a zisteným vrcholom. Nadmorská výška tejto línie systematicky klesá (povolená malá tolerancia na stúpanie) smerom od vrcholu k testovanej ploche,

- plocha ešte nebola zaradená do inej entity,

- vztažný bod plochy je $\mathrm{k}$ danému vrcholu bližšie ako je limita (max. predpokladaná šírka koruny/2),

- rozdiel medzi n.m.v. plôch je nižší ako stanovená prahová hodnota. ku 6.

Graficky je uvedený postup zobrazený na obráz-

Limita (maximálna očakávaná šírka koruny) je definovaná ako polovica priemeru koruny najkošatejšieho stromu v skúmanej oblasti. Žiadna entita získaná vyhodnotením údajov preto nemôže mat väčší polomer. Z praktického hladiska postačí kvalifikovaný odhad priemeru plošne najväčších stromov v stereo móde PhoTopoL.

V poslednom kroku algoritmu vymedzenia korún stromov sme spojili výsledky oboch variant rozlíšenia korún do jedného výstupu. Vychádzame pritom z empiricky zistenej skutočnosti, že vrcholy zistené na základe analýzy DMT sú menej početné ale spolahlivejšie ako vrcholy zistené analýzou vrstvy DMR. Preto berieme entity z DMT ako základ konečného výstupu. Pri určení vrcholu stromu môžu nastat tieto situácie:

a) patrí do entity odvodenej z DMT,

b) patrí súčasne do entity odvodenej z DMT ako aj DMR (v ideálnom prípade tzv. prekryv korún),

c) patrí do entity pôvodom z DMR,

d) plôšku sa nepodarilo priradie k žiadnemu vrcholu (v ideálnom prípade tzv. redukovaná holina).

Za pevne stanovený vrchol koruny stromu považujeme výstup z prvého kroku odvodený z DMT. Do výstupu sa d’alej zahrnú tie entity z druhého kroku, ktorých jedinečnosî vo vztahu k entitám z DMT nie je spochybnená. Pre vylúčenie duplicitného evidovania entít (korún stromov) sme stanovili prahovú hodnotu - limitu v hodnote max. vel'kosí korún/2 (polomer koruny). V prípade porastov na našom modelovom území ide o hodnotu $5 \mathrm{~m}$. To znamená, že algoritmus neprevezmeme do výstupu entitu z DMR, ktorej vrchol leží bližšie ako $5 \mathrm{~m}$ k vrcholu entity pôvodom z DMT. V týchto prípadoch predpokladáme, že vrcholy zobrazujú ten istý objekt (strom). Konečný výstup obsahuje tieto objekty:

a) vrcholy (body) zistené na základe DMT,

b) vrcholy (body) zistené na základe DMR plôšky po
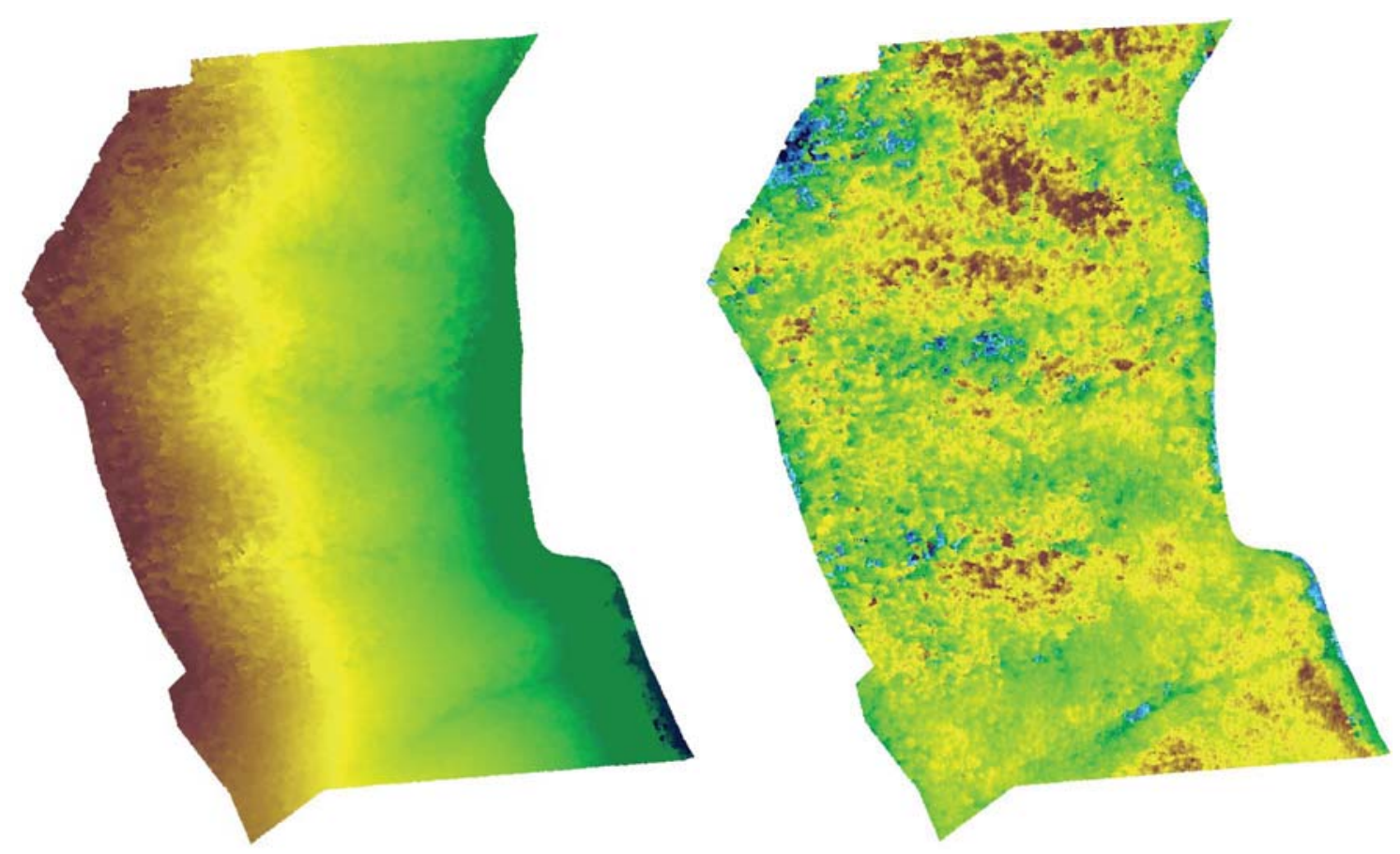

Obr. 5. Vlavo: Digitálny model povrchu korún z modelového územia Medvedia úboč. Kolorovanie plôch podla nadmorskej výšky povrchu korún porastu od zelenej po hnedú (najvyššia nadmorská výška). Vpravo: Výšky stromov v poraste vypočítané z rozdielu DMT a DMR. Kolorovanie plôch podla výšky povrchu korún porastu od najnižšej (modrá) po hnedú (nadúrovňové stromy). Modré hodnoty HVR $<0$, HVR $>0$ škála od zelenej po tmavohnedú

Fig. 5. Left: A digital model of the of forest canopy in the research area of Medvedia úboč. Coloring the areas by altitude of the tree tops in a forest stand from green to brown (highest altitude). Right: Height of trees in the forest stand calculated from the difference between DMT and DMR. Coloring the areas by heights of the tree tops from the lowest (blue) to brown (dominant trees). Blue values $H V R<0, H V R>0$ range from green to darkbrown 


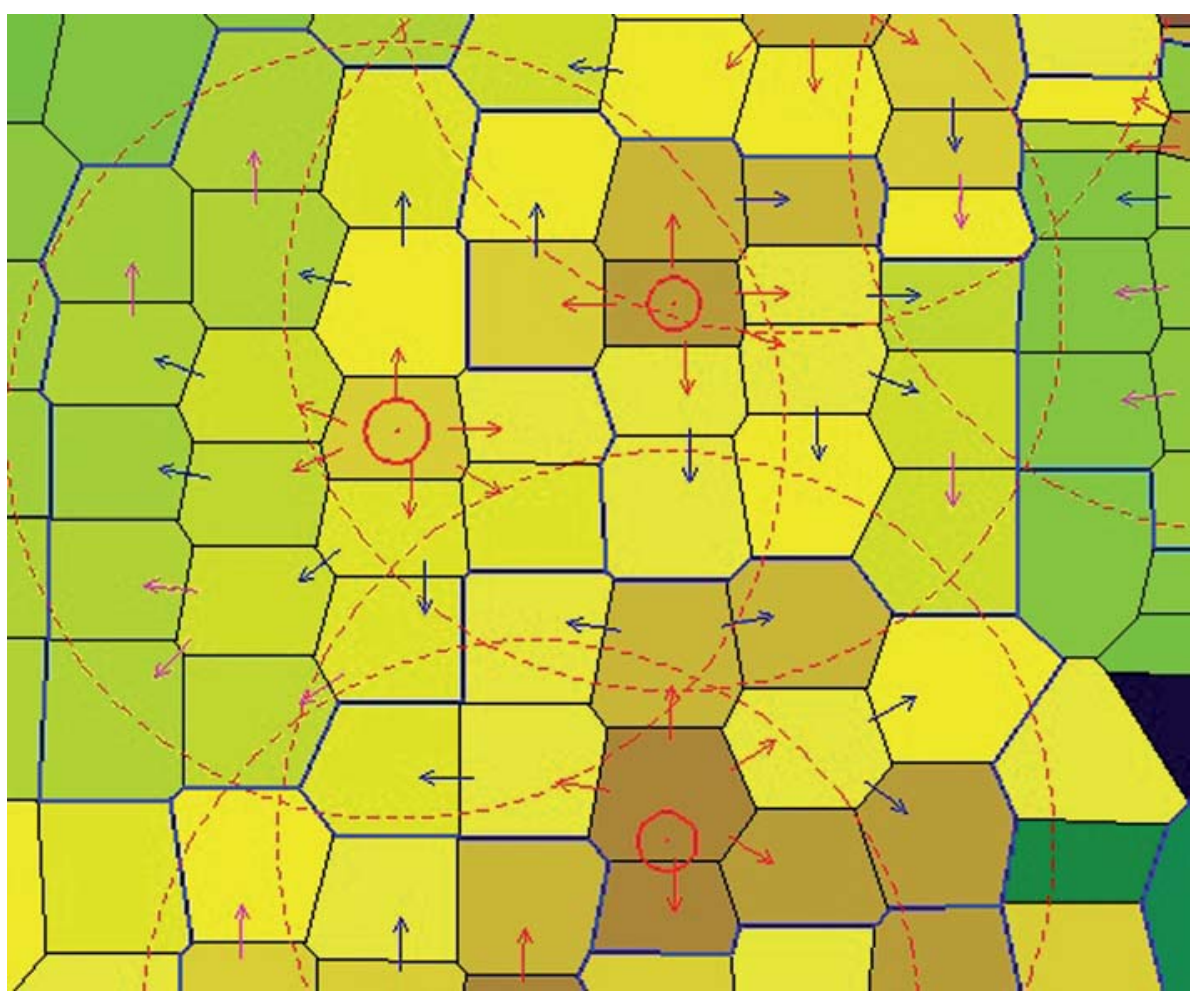

Obr. 6. Prirad’ovanie plôch k entite. Plôška s kruhom reprezentuje vrchol stromu. Entita sa rozširuje postupným priberaním nižších a ešte neobsadených plôch, pokial’ nie je zastavená niektorou z limitných (prahových hodnôt). Limita max. šírky koruny je vyznačená na obrázku kružnicami (čiarkovane). Jednotlivé plôšky sú priradované po etapách. Etapa prebehne naraz pre všetky entity. Na obrázku etapu 1 znázorňuje červená šípka, 2. etapu modrá, šípky d’alších etáp sú ružové

Fig. 6. Assigning areas to the entity. Area with a circle represents the tree top. Entity extends gradually by taking the lower and free areas, unless it is terminated by one of the limits (threshold value). Limit of the maximum crown width is marked with dash circles in the figure. Individual areas are assigned in stages. One stage takes place once for all entities. Figure 1 shows 1. stage with a red arrow, 2. stage with blue, other phases with pink arrow

testovaní jedinečnosti vrcholu stromu (limita $1 / 2$ vel'kosti koruny),

c) línie reprezentujúce obvod korún stromov.

\subsection{Vyhodnotenie správnosti vymedzenia korún stromov}

Správnosî vymedzenia korún sme overili na 5 plochách, na ktorých sme vykonali podrobné terestrické šetrenia a merania. Po zameraní pozícií stromov na ploche boli stromy zaradené podla ich výškového postavenia do 4 tried v zmysle ZlatníKa (1976). Prehlad zastúpenia jednotlivých tried udáva tabul'ka 2. Z hladiska drevinového zloženia ide na plochách VX1, VX4 a VX5 o zmiešané porasty buka s jedlou. Na ploche VX3 prevláda v zastúpení jedla s primiešaným bukom a smrekom, na ploche VX8 dominujú listnaté dreviny, zastúpené sú buk, jaseň štíhly, javor horský a javor mliečny, vtrúsená je jedla.

Na všetkých 5 plochách ide o viacvrstvové porasty. V d’alšom sú vyhodnocované len stromy výškového postavenia 1 a 2 , t. j. nadúrovňové a úrovňové stromy. Stromy podúrovňové (výškové postavenie 3 a 4) je možné pri prehustlom a ani pri uvolnenom zápoji z leteckých snímok identifikovat. Uvedené konštatovanie je založené na vizuálnom určení stromov na obrazovke monitora v 3-D zobrazení a porovnaní týchto výsledkov s terestricky zisteným počtom stromov na plochách (tab. 3).

Pre porovnanie terestrických meraní s výsledkami odvodenými zo snímok bolo potrebné čo najpresnejšie polohovo zosúladie jednotlivé plochy na úrovni stotožnenia jednotlivých stromov. Stotožnenie sa vykonalo na základe vizuálneho posúdenia vzájomného posunu na obrazovke monitora, kde sme položili polygónovú vrstvu priemetu korún stromov na stereo model leteckej snímky. Vel'kosî posunu v teréne zameraných plôch vzhl'adom $\mathrm{k}$ snímke sa pohybovala od $4,2 \mathrm{~m}$ pri ploche VX4 po $7,5 \mathrm{~m}$ pri ploche VX5.

Z výsledkov v tabul'ke 3 vyplýva dobrá zhoda medzi terestrickým a operátorom na 3-D modeli odvodeným počtom stromov na plochách č. VX1, VX3 a VX4. Chyba určenia počtu stromov sa pohybuje o 0 do $+10 \%$, čo znamená, že operátor počet stromov nadhodnotil. Na plochách VX5 a VX8 operátor počet stromov podhodnotil o $22 \%$, resp. o $20 \%$.

V tabul'ke 4 sú porovnané automatizovane vymedzené koruny s terestrickými meraniami na uvedených 5 plochách. Automatizovaná klasifikácia na plochách 
VX1, VX3, VX4 a VX5 viedla k podhodnoteniu počtu stromov na plochách od 14 do $41 \%$. Opačný výsledok, nadhodnotenie o $40 \%$ sme dosiahli na ploche VX8. Ide o plochu s takmer $100 \%$ zastúpením listnatých drevín. Podla výsledkov v tabul'ke 3 pri uvedenej ploche operátor naopak počet stromov podhodnotil. To potvrdzuje poznatky z literatúry (Косн et al. 2006) na problémy určenia korún stromov v listnatých zapojených porastoch.
Výsledky publikované v tabulkách 3 a 4 poukazujú na to, že tak operátor na 3-D modeli ako aj automatizovaná klasifikácia stromov v priemere podhodnocujú počet stromov oproti referenčnému terestrickému zistovaniu. Vel'kosł podhodnotenia o $-5 \%$, resp. $-15 \%$ za všetky plochy spolu poukazuje na možné využitie prezentovaných prístupov pri odvodení porastových charakteristík (počtu stromov v poraste). Menšie podhodnotenie ako aj menšie variačné rozpätie od $-22 \%$ do $+10 \%$ bolo dosiah-

Tabul'ka 2. Zaradenie stromov na výskumných plochách podla ich výškového postavenia (ZLATNík 1976)

Table 2. Categorization of tree on research areas according to their height position (ZlatNíK 1976)

\begin{tabular}{|c|c|c|c|c|c|c|c|}
\hline \multirow{2}{*}{ Plocha č. ${ }^{1)}$} & \multicolumn{6}{|c|}{ Terestrické merania: počet stromov s výškovým postavením²) } & \multirow[b]{2}{*}{ Priemerná výška ${ }^{4)} 1+2$} \\
\hline & 1 & 2 & 3 & 4 & Spolu ${ }^{3)}$ & Spolu ${ }^{3)} 1+2$ & \\
\hline VX1 & 11 & 10 & 8 & 16 & 45 & 21 & 34,5 \\
\hline VX3 & 5 & 22 & 14 & 28 & 69 & 27 & 26,1 \\
\hline VX4 & 3 & 16 & 23 & 26 & 68 & 19 & 30,4 \\
\hline VX5 & 7 & 16 & 14 & 81 & 118 & 23 & 31,2 \\
\hline VX8 & 6 & 14 & 8 & 18 & 46 & 20 & 33 \\
\hline Spolu $^{3)}$ & 32 & 78 & 67 & 169 & 346 & 110 & 31,04 \\
\hline
\end{tabular}

${ }^{1)}$ Plot code, ${ }^{2}$ Terrestrial measurement (number of trees and height status), ${ }^{3)}$ Total, ${ }^{4)}$ Average height $1+2$

Tabul'ka 3. Porovnanie terestricky zistených a operátorom určených korún stromov na 5 plochách Table 3. Comparison of terrestrially determined tree tops and tree tops detected by operator on 5 areas

\begin{tabular}{|c|c|c|c|c|}
\hline Plocha ${ }^{1)}$ & $\begin{array}{l}\text { Terestrické meranie } \\
\text { (počet stromov) }^{2)}\end{array}$ & Operátor na 3-D modeli3) & Rozdiel $^{4)}$ & Chyba v \% \\
\hline VX1 & 21 & 23 & +2 & +10 \\
\hline VX3 & 27 & 28 & +1 & +4 \\
\hline VX4 & 19 & 19 & 0 & 0 \\
\hline VX5 & 23 & 18 & -5 & -22 \\
\hline VX8 & 20 & 16 & -4 & -20 \\
\hline Spolu' & 110 & 104 & -4 & -5 \\
\hline
\end{tabular}

+ chyba nadhodnotenia - Error of overestimation, - chyba podhodnotenia - error of underestimation

${ }^{1)}$ Plot code, ${ }^{2)}$ Terrestrial measurement (number of trees), ${ }^{3)}$ Operator of $3 D$ model, ${ }^{4)}$ Difference, ${ }^{5}$ Errors in \%, ${ }^{6}$ Together

Tabul'ka 4. Porovnanie terestricky zistených a automatizovane vymedzených korún na 5 plochách

Table 4. Comparison of terrestrially determined tree tops and automatically detected tree tops on 5 areas

\begin{tabular}{|c|c|c|c|c|}
\hline Plocha $^{1}$ & $\begin{array}{c}\text { Terestrické meranie } \\
\text { (počet stromov) }^{\mathbf{2})}\end{array}$ & $\begin{array}{c}\text { Automatizovaná } \\
\text { klasifikácia }^{3}\end{array}$ & Rozdiel $^{\mathbf{4})}$ & Chyba v \% $^{\mathbf{5}}$ \\
\hline VX1 & 21 & 18 & -3 & -14 \\
\hline VX3 & 27 & 16 & -11 & -41 \\
\hline VX4 & 19 & 16 & -3 & -16 \\
\hline VX5 & 23 & 16 & -7 & -30 \\
\hline VX8 & 20 & 28 & +8 & +40 \\
\hline Spolu6) & 110 & 94 & -16 & -15 \\
\hline
\end{tabular}

+ chyba nadhodnotenia - Error of overestimation, - chyba podhodnotenia - error of underestimation.

${ }^{1)}$ Plot code, ${ }^{2}$ Terrestrial measurement (number of trees), ${ }^{3)}$ Automated classification, ${ }^{4}$ Difference, ${ }^{5}$ Errors in \%, ${ }^{6}$ Together 
Tabul'ka 5. Porovnanie automatizovane klasifikovaných a operátorom vymedzených korún, ktoré bolo možné polohovo jednoznačne stotožni

Table 5. Comparison of automatically determined tree tops and tree tops detected by operator, that can be exactly identified in a position

\begin{tabular}{|c|c|c|c|}
\hline Plocha1) $^{1}$ & Operátor na 3-D modeli2) & $\begin{array}{c}\text { Automatizovaná klasifikácia / } \\
\text { z toho stotožnených }{ }^{3)}\end{array}$ & $\begin{array}{l}\text { Správnost klasifikácie pre prípad } \\
\text { stotožnených stromov }(\%)^{4)}\end{array}$ \\
\hline VX1 & 23 & $18 / 14$ & 61 \\
\hline VX3 & 28 & $16 / 9$ & 32 \\
\hline VX4 & 19 & $16 / 12$ & 63 \\
\hline VX5 & 18 & $16 / 10$ & 56 \\
\hline VX8 & 16 & $28 / 11$ & 69 \\
\hline Spolu ${ }^{5)}$ & 104 & $94 / 56$ & 54 \\
\hline
\end{tabular}

${ }^{1)}$ Plot code, ${ }^{2}$ Operator of $3 \mathrm{D}$ model, ${ }^{3)}$ Automated classification/from that clearly assigned to the reference trees, ${ }^{4}$ Classification accuracy for a case of clearly assigned trees, ${ }^{5}$ Together

nuté pri vizuálnom určení korún stromov operátorom na 3-D snímky. Vel'ké variačné rozpätie od - $41 \%$ do +40\% $\mathrm{v}$ prípade automatizovanej klasifikácie poukazuje na potrebu spresnenia algoritmu vymedzenia korún alebo nastavenia parametrov algoritmu podla stavových parametrov porastu (vek, drevinové zloženie).

Pri uvedenom vyhodnotení správnosti určenia korún stromov nebolo brané v úvahu polohové stotožnenie stromov na analyzovaných plochách. Porovnané boli len počty stromov, čo môže viest k nadhodnoteniu správnosti ich určenia. Pre posúdenie vel'kosti nadhodnotenia sme vykonali klasifikáciu správnosti len na stotožnených stromoch. Postup sme založili na porovnaní korún stromov určených automatizovanou klasifikáciou a tými korunami, ktoré operátor vizuálne vymedzil a následne stotožnil s klasifikáciou na 3-D modeli na obrazovke monitora. Výsledky sumarizujeme v tabul'ke 5.

Z výsledkov vyplýva, že percento stotožnených stromov sa pohybuje od 32 do $69 \%$, v priemere za všetky plochy $54 \%$. Ide o výsledok, ktorý nepovažujeme za dostatočný pre uplatnenie postupu v hospodársko-úpravníckej praxi. Poukazuje na potrebu podstatnejšieho dopracovania navrhnutého algoritmu vymedzenia korún. Treba poznamenat, že proces polohového stotožnenia korún zameraných terestricky s korunami na snímke je závislý od rozhodnutia operátora, od jeho vyhodnotenia a eliminácie vzájomných posunov vyplývajúcich z chýb zamerania plochy a stromov, presnosti fotogrametrického modelu, naklonenia stromu, viditelnosti koruny atd'.

\section{Diskusia}

Náš experiment potvrdzuje, že vývoj algoritmov v oblasti spracovania a klasifikácie leteckých snímok vedie $\mathrm{k}$ postupnému zvyšovaniu presnosti a správnosti odvodenia stromových a porastových veličín. Kým Mallinger (1997 in Koch 2006) konštatoval, že 3-D model povrchu korún je nepresný a preto nevhodný pre odvodenie stromových a porastových charakteris- tík lesných porastov, AdLER (2001) už dosiahla $45 \%$ správnosê automatickej identifikácie korún stromov v ihličnatých porastoch. Problémom bola predovšetkým vel'ká spektrálna rozdielnosí osvetlenej a zatienenej časti koruny. WASER et al. (2006) dosiahli $74 \%$ správnosí určenia jednotlivých stromov z CIR snímok v kombinácii s lidarovými údajmi. Majlingová (2007) pri využití infračervených snímok dosiahla správnosê klasifikácie $71 \%$ v počte vymedzených stromov, resp. $55 \%$ v počte stromov jednoznačne stotožnených s referenčnými stromami. Косн et al. (2006) využili pre ohraničenie korún 3-D model povrchu korún odvodený z lidarových údajov. Pri poraste douglasky tisolistej zo 49 stromov určili automatizovane 47 , z čoho až $87,3 \%$ jednoznačne stotožnili s pozemnými šetreniami. Pri listnatých porastoch (hrab obyčajný, javor horský, jaseň štíhly zo 49 stromov automatizovane vymedzili 30 a z nich bolo možné len polovicu (50\%) jednoznačne prisúdit k referenčným stromom zameraným terestricky. V porovnaní s fotogrametrickým určením referenčných stromov bolo jednoznačne stotožnených $61,7 \%$ automatizovane vymedzených korún. Autori konštatujú, že pri zapojených listnatých porastoch navyše výškovo homogénnych algoritmus separácie korún stromov zlyháva. Túto skutočnosî potvrdzuje aj náš výsledok na ploche VX8, ked' pri automatizovanej klasifikácii došlo $\mathrm{k}$ nadhodnoteniu o $40 \%$ a naopak pri vyhodnotení korún operátorom na 3-D modeli k podhodnoteniu o $20 \%$.

Z konfrontácie s výsledkami citovaných prác vyplýva, že výsledky dosiahnuté nami navrhnutým algoritmom pre LMMS s vysokým rozlíšením sú porovnatelné s výsledkami dosiahnutými citovanými autormi. Dosiahnutá $95 \%$ správnosê v počte stromov určených operátorom na obrazovke $\mathrm{v}$ porovnaní $\mathrm{s}$ terestrickým zistením na všetkých výskumných plochách spolu (tab. 3) ako aj $85 \%$ správnosé automatizovaného vymedzenie korún k terestrickému zisteniu (tab. 4) sa javí ako perspektívna pre praktické využitie na úrovni zistovania 
porastu. Vel'ké variačné rozpätie chýb pri automatizovanej klasifikácii na skusných plochách však poukazuje na potrebu spresnenia modelu. Na d'alšie nedostatky algoritmu poukázalo porovnanie automatizovane klasifikovaných a operátorom určených korún, ktoré bolo možné polohovo jednoznačne stotožnit. Správnosê bola $\mathrm{v}$ tomto prípade len $54 \%$ (tab. 5). Tieto výsledky naznačujú, že okrem doladenia algoritmu bude nutné do neho zahrnút aj d’alšie kritériá a vstupné parametre ako, napr. spektrálne charakteristiky, prípadne kombinovat snímku $\mathrm{s}$ údajmi laserového skenovania.

Ďalším limitujúcim faktorom je možnosê vymedzenia len úrovňových a nadúrovňových stromov. Z pohladu využitia odvodeného počtu stromov a vel'kosti korún pri odhade zásob sa táto skutočnosî nemusí javit ako rozhodujúca, vzhladom k tomu že hlavná časê zásoby sa kumuluje v jedincoch výškového postavenia 1 a 2 .

Algoritmus odvodenie DMT z leteckých snímok $\mathrm{v}$ presnosti potrebnej pre určenie $\mathrm{v}$ práci opísaných stromových charakteristík je výpočtovo náročný. Pri sieti výškových bodov $2 \times 2 \mathrm{~m}$ sme sa už na modelovom území asi 100 ha dostali k stovkám tisícom objektov, navyše s 3-D záznamom (x, y, z súradnica). Bežný 32 bitový softvér má navyše limitovanú správu pamäte schopnostou adresovat pamät maximálne na $2^{32}$ byte, čo limituje množstvo objektov, ktoré je možné efektívne spracovat.

Ďalším obmedzením, s ktorým sme sa stretli v našej analýze bolo zlyhanie algoritmu pre odvodenie bodov digitálneho modelu povrchu porastu v nadire snímky. Ide o výrazné obmedzenie, pričom nie je z našej práce možné zovšeobecnił či ide o neriešitel'ný fotogrametrický problém alebo o nedostatok algoritmu použitého softvéru.

Pre zistenie plôch, ktoré sú výškovo dominantné a je predpoklad, že budú zodpovedå vrcholom stromov, boli napísané aplikačné formuláre v internom jazyku PhoTopoLu, v jazyku Topas. Nevýhodou tohto makro jazyka je pomalý prístup $\mathrm{k}$ dátam a nemožnosî dynamického programovania. V prípade spracovania väčších území by bolo vhodné prepísat formuláre do iného jazyka ako externé programy.

\section{Záver}

Digitálne multispektrálne snímky s vysokým rozlíšením $20 \times 20 \mathrm{~cm}$ sa stali štandardom v lesníckom mapovaní. Pri ich spracovaní sa už rutinne zaviedli metódy digitálnej fotogrametrie. Vytvorili sa tak predpoklady pre rozvoj špecializovaných aplikácií v oblasti tematického lesníckeho mapovania založené na využití leteckých meračských snímok.

Dosiahnuté výsledky nie sú zatial' vyhovujúce pre uplatnenie sa v rámci hospodársko-úpravníckych prác. V d’alšom výskume sa sústredíme na kombináciu fotogrametrického a spektrálneho prístupu. Klúčovou úlohou je vykoną ortorektifikáciu snímok podla DMT odvodeného z fotogrametrického modelu a tým zabezpečit polohové zjednotenie výstupov z fotogrametrického a spektrálneho vyhodnotenia snímok. Vzájomnou kombináciou prístupov sa rozšíri systém kritérií pre vymedzenie korún a vrcholov stromov. Ďalší možný smer výskumu je zapracovanie trigonometrických vztahov definujúcich pozíciu slnko - strom - tieň do algoritmu určenia vrcholov stromov v 3-D priestore. Perspektívne sa javí aj prepojenie digitálnej fotogrametrie a pozemného laserového skenovania, a to predovšetkým pre potreby odvodenia výšok jednotlivých stromov ako aj strednej a hornej výšky porastu. Precíznejšie odvodenie DMR je predpokladom pre d'alšie rozvinutie problematiky určenia výšok stromov a s ňou súvisiacej problematiky hodnotenie vertikálnej výstavby porastov.

\section{Pod'akovanie}

Táto práca bola podporovaná Agentúrou na podporu výskumu a vývoja na základe zmluvy č. APVV-0632-07, v rámci projektu „Výskum metód klasifikácie a štrukturálnych modelov priaznivého stavu lesných ekosystémov Slovenska - hodnotenie stavu a vývoja lesov v krajine s podporou DPZ“.

\section{Literatúra}

ADLER P., 2001: Einsatz digitaler Photogrammetrie zur Beschreibung von Waldbeständen. Am Beispiel der digitalen photogrammetrischen Erfassung der Level 2 Flächen Baden-Württemberg. Dissertation an der Albert-Ludwigs-Universität, Freiburg. 148 p.

Bucha T., Vladovič J., 2000: Klasifikácia zdravotného stavu lesov pomocou kozmických snímok Landsat TM na modelovom území Lomnistej a Vajskovskej doliny. Lesnícky časopis - Forestry Journal, 46(2): 117-127.

HalvoŇ L., 2008: Lesnícke mapové dielo. In: Lesnícka geodézia a fotogrametria - trendy. Zvolen: TU Zvolen, s. 112-132.

Chubey M.S., Franklin S.E., Wulder M., 2006: Object-based Analysis of Ikonos-2 Imagery for Extraction of Forest Inventory Parameters. Photogrammetric Engineering \& Remote Sensing, 72(4): 383-394.

Kim M., MAdDEn M., 2006: Determination of optimal scale parameter for alliance-level Forest classification of multispectral ikonos images. 1st International Conference on Object-based Image Analysis (OBIA 2006), ISPRS, Volume No. XXXVI - 4/C42, ISSN 1682-1777.

Koch B., Heyder U., Straub Ch., Weinacker H., 2006: 3-D data for forest and environmental planning. In: KouKaL, T., SCHNEIDER, W. (eds): 3-D Remote Sensing in Forestry, International workshop ERSeL - Vienna, p. 1-14.

KRсно J., 1990: Morfometrická analýza a digitálne modely georeliéfu. Bratislava: VEDA.

MAJuInGová A., 2007: Digitálna obrazová analýza dát DPZ s vysokým priestorovým rozlíšením a jej využitie v lesníctve. GIS-Ostrava 2007. Dostupné na internete: http://gis.vsb.cz/GIS_Ostrava/ GIS_Ova_2007/sbornik/Referaty/Sekce2/majlingova.pdf

MATĚJKA K., 2007: Assessment of tree layer biomass and structure using Aerial photos in lake catchments of the Šumava Mts. Journal of Forest Science, 55(2): 63-74.

Person A., Holmgren J., Söderman U., 2006: Identification of tree species of individual trees by combining very high resolution laser data with multi-spectral images. In: Koukal T., SCHNEIDER W. (eds.): 3-D Remote Sensing in Forestry, International workshop ERSeL - Vienna, p. 102-107. 
Radoux J., Defourny P., 2006: Influence of image segmentation parameters on positional and Spectral quality of the derived objects. $1^{\text {st }}$ International Conference on Object-based Image Analysis (OBIA 2006), ISPRS, Volume No. XXXVI - 4/C42, ISSN 1682-1777.

Townshend J.R.G., Huang ., Kalluri S.N.V., Defries R.S., Liang S., 2000: Beware of Per-pixel Characterization of Land Cover. International Journal of Remote Sensing, 21(4): 839-843.

ŠUMBERA S., ŽIDEK V., 2002: Automated tree top identification using colour infrared aerial photograps of high spatial resolution. Ecology (Bratislava), 21(3): 229-238.

SCHEER L., 1995 : Zistovanie zásob dvojfázovým regresným výberom pomocou družicových scén a terestrického merania. Lesnictví-Forestry, 41(5): 224-229.

Šmelko Š., Scheer L., Petráš R., Ďurský J., Fabrika M., 2003: Meranie lesa a dreva. Zvolen: ÚVVP LVH SR, 239 s.

Wang Y., Soh S.Y., Schultz H., 2006: Individual tree crown segmentation in aerial forestry images by mean shift clustering and graph-based cluster merging. Intrernational Journal of Computer Science and Network Security, 6(11):40-45.

Waser L.T., Ecker K., Ginzler Ch., Küchler M., Schwarz M., Thee P., 2006: Extraction of forest parameters in a mire environment using airborne spectral data and digital surface models. In: KouKAL T., SchneIDER W. (eds.): 3-D Remote Sensing in Forestry, International workshop ERSeL - Vienna, p. 15-23.

Wolf B-M., HeIPKE CH., 2007: Automatic extraction and delineation of single trees from remote sensing data. Machine Vision and Applications, 18(5): 314-330.

ZlatNík A., 1976: Lesnická fytocenologie. Praha: SZN.

Žıhlavní Š., ChúdY F., Kardoš M., 2005: Digitálna fotogrametria v lesníckom mapovaní. Zvolen: Technická univerzita vo Zvolene, ISBN 80-228-1545-4, $80 \mathrm{~s}$.

Dostupné na internete: http://www.microsoft.com/ultracam/downloads/default.mspx

Základná mapa SR, 1 : 10 000, Geodetický a kartografický ústav, dostupné na internete ako webová mapová služba: http://atlas. sazp.sk/wmsconnector/com.esri.wms.Esrimap?ServiceName=share_raster_zakladne_mapy\&

\section{Summary}

This paper deals with derivation of a method for crown detection from a 3-D model of forest canopy created from multi-spectral aerial stereo photos with a high resolution. Test area Medvedia úboč of approx. 100 ha is situated in a terrain with an average gradient of $32^{\circ}$. There are aged fir-beech multi-layered stands mixed with maple, ash and spruce.

3-D model of forest canopy (DMT) is derived from photos using methods of digital photogrammetry (Fig. 3). We created an angle network from the point array of heights, i.e. area was assigned to each height point automatically. There are generated topological and geometric relationships (adjacent, higher, lower, ...) by defining area around elevation points. These can be used to determine tree crowns by formulation of mathematical and logical criteria derived from the knowledge of the size and shape of the tree crown:
Firstly, we have to determine the tree tops in a group of areas (polygons). We have checked two variants. Variant A) determines the tree tops in a group of areas from DMT with absolute altitudes. The tree top is field reference point (gravity centre of the area), which altitude is higher then altitude of other neighboring areas (Fig. 5 on the left). If there are two or more tree top areas next each other, these are aggregated and the reference point of the new (merged) area is becoming the top. The methodology procedure in Variant B) was the same, but instead of an absolute altitude we used the height difference from digital model of forest canopy and digital relief model: HVR = DMT - DMR (Fig. 5 on the right). Digital relief model was derived from contour lines on a basic map of SR in a scale of $1: 10000$.

Secondly, we assigned broader area to the tree top - entity (Fig. 6). Under the entity we understand a group of areas appertaining to a single top. Therefore, entity represents a tree crown. The individual areas are assigned to entity based on the following criteria:

- Altitude of the area is lower than the top.

- Test area in relation to the top lies on the imaginary line formed by the centre of gravity of the areas lying between the tested area and the detected top. Altitude of this line systematically decreases from the top of the test area.

- Area has not yet been assigned to any other entity.

- Reference point of the area is closer to the top than a limit (maximum estimated crown width / 2).

- The difference between altitudes of the areas is lower than the set threshold level.

Third (final) step combines the results of both variants of tree tops detection into one single output. A fixed tree top is considered to be an output from the first step derived from DMT. Output includes also those entities from the second step that are undisputed in relation to the entities from DMT. In our solution the algorithm does not take any entity of DMR into the output with top lying closer than 5 meters to the top of the entity from the DMT. We assume that the tops display the same object (tree) in these cases.

Tree tops represent the number of trees in the forest stand. Their correct determination was checked on the five research plot. We could not identify subdominant and suppressed trees from aerial photos. Therefore, we evaluated only trees of height 1 and 2, i.e. dominant and co-dominant trees (Table 2). Table 3 shows a comparison between the number of tree terrestrially determined on 5 research areas and the number of trees determined by operator from the images on the screen. Error of determining the number of trees ranges from $-22 \%$ (i.e. operator underestimated the number of trees in the area) to $+10 \%$ (i.e. operator overestimated the number of trees).

Table 4 shows a comparison of terrestrially determined and automatically detected tree tops on 5 research areas. Errors of the automated classification were in the range from $-41 \%$ to $+40 \%$ when compared with terrestrial measurements. It is required to include also other criteria into the algorithm for other detailed classification. It will concern particularly use of spectral information in the determination of the tree crown.

Translated by J. LÁSKOVÁ 